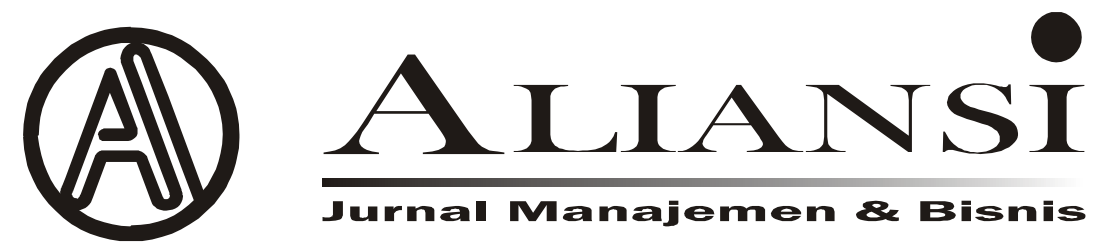

\title{
ANALISIS RASIO PROFITABILITAS SEBAGAI ALAT UNTUK MENILAI KINERJA KEUANGAN PADAPT.ACE HARDWARE INDONESIA TBK (AHI)
}

\author{
Oleh : Indri Astuti dan Eka Safitri \\ email : kaffah03@yahoo.com
}

\begin{abstract}
This research aimed to examine the effect of Return on Assets (ROA), Return on Equity (ROE) and Net Profit Margin (NPM) on the financial performance of PT. Ace Hardware Indonesia Tbk (AHI) which were listed on Indonesia Stock Exchange. While, the data were secondary, in which taken from company's financial statement 2014-2017. Moreover, the research was quantitative. In addition, the data analysis technique used descriptive statistics and inferential analysis with SPSS 25. From the data result, it concluded Return on Assets, Return on Equity, Net Profit Margin, and financial performance had good average score. Likewise, from the inferential analysis, it showed classical assumption test of all variables had fulfilled the assumption and there was no violence. As well as from the proper test model, it showed regression model was properly used. In brief, from the hypothesis result, it concluded Return on Assets and Return on Equity had significant effect on the financial performance. On the other hand, Net Profit Margin had insignificant effect on the financial performance.

Keywords : roa,roe, npm, financial performance
\end{abstract}

\section{PENDAHULUAN}

\section{Latar Belakang Masalah}

Suatu kegiatan usaha (bisnis) yang dijalankan oleh suatu perusahaan, tentulah memiliki beberapa tujuan yang ingin dicapai oleh pemilik dan manajemen, salah satunya yaitu pemilik perusahaan menginginkan keuntungan yang optimal atas usaha yang dijalankannya. Bagi pihak manajemen, keuntungan yang diperoleh merupakan pencapaian rencana (target) yang telah ditentukan sebelumnya. Pencapaian target keuntungan sangat penting karena dengan mencapai target yang telah ditetapkan atau bahkan melebihi target yang diinginkan, hal ini merupakan prestasi tersendiri bagi pihak manjemen. Prestasi ini merupakan ukuran untuk menilai kesuksesan manajemen dalam mengelola perusahaan. Agar tujuan tersebut dapat dicapai, manajemen perusahaan harus mampu membuat perencanaan yang tepat dan akurat. Kemudian, agar usaha yang dijalankan dapat dipantau perkembangannya, setiap perusahaan harus mampu membuat catatan, pembukuan, dan laporan terhadap semua kegiatan usahanya. Catatan, pembukuan, dan laporan tersebut dibuat dalam suatu periode tertentu dalam bentuk laporan keuangan.
Kinerja keuangan merupakan suatu usaha formal untuk mengevaluasi efisiensi dan efektivitas perusahaan dalam menghasilkan laba dan posisi kas tertentu.. Analisis kinerja keuangan merupakan suatu proses pengkajian kinerja keuangan secara kritis, yang meliputi peninjauan data keuangan, perhitungan, pengukuran, dan pemberian solusi terhadap masalah keuangan perusahaan pada suatu periode tertentu. Jadi dalam menilai kinerja keuangan perusahaan, dapat digunakan suatu ukuran atau tolak ukur tertentu. Biasanya ukuran yang digunakan adalah rasio atau indeks yang menghubungkan dua data keuangan.

Adapun jenis perbandingan dalam analisis rasio keuangan meliputi dua bentuk yaitu membandingkan rasio masa lalu, saat ini ataupun masa yang akan datang untuk perusahaan yang sama, dan bentuk yang lain yaitu dengan perbandingan rasio antara satu perusahaan dengan perusahaan lain yang sejenis. Perkembangan teknologi jika dibandingkan dengan beberapa tahun sebelumnya tentu meningkat pesat. Salah satunya adalah peralatan rumah tangga. Peralatan rumah tangga saat ini dinilai sangat canggih sehingga dapat mempermudah pekerjaan sehari-hari.

Banyaknya kemudahan yang diberikan dalam suatu produk tersebut sangat menarik minat

1* Dosen Program Strata Satu Manajemen Sekolah Tinggi Manajemen IMMI 
konsumen untuk membeli produknya. Salah satu tempat yang seringkali dikunjungi konsumen untuk mencari peralatan ruman tangga ialah Ace Hardware. Tempat ini seringkali dikunjungi oleh konsumen karena produk yang tersedia cukup lengkap dengan beragam merk dan harga, mulai dari yang termurah hingga termahal. Selain peralatan rumah tangga, Ace Hardware juga menyediakan beragam kebutuhan lifestyle seperti automotive, furniture, houseware and gift, sporting goods and pet supplies, serta home appliances. Perusahaan ini seringkali memberikan diskon harga yang menguntungkan sehingga semakin menarik minat konsumen. Selain gerai offline, perusahaan ini juga mluncurkan layanan dalam bentuk online berupa situs belanja online bernama "Ruparupa" (www.ruparupa.com). Dengan hadirnya situs ini diharapkan dapat menjadi solusi bagi pelanggan yang ingin berbelanja produk Ace Hardware dari manapun dan kapanpun. Selain itu, dengan adanya situs ini, diharapkan akan menambah keuntungan bagi perusahaan, karena kemudahan yang diberikan. Mungkin banyak daerah-daerah yang belum tersentuh oleh perusahaan ini, sehingga pelanggan yang ingin membeli produk Hardware harus menempuh perjalanan yang cukup jauh. Namun dengan adanya situs ini, tentu pelanggan akan lebih mudah untuk mengakses dan berbelanja. Dengan banyaknya gerai offline di seluruh Indonesia, ditambah dengan situs belanja online, Ace hardware telah berupaya keras untuk meningkatkan kinerja keuangannya. Untuk memastikan bahwa tujuan perusahaan dapat tercapai dan mengetahui sejauh mana efektifitas operasi perusahaan dalam mencapai tujuan maka secara periodik dilakukan pengukuran kinerja perusahaan. Berikut merupakan tabel yang menggambarkan posisi keuangan PT. Ace Harware Indonesia Tbk (AHI) selama empat tahun:

Tabel I.1 Laba/ Rugi dan Penjualan PT. Ace Harware Indonesia Tbk (AHI) tahun 2016-2019

\begin{tabular}{|c|c|c|}
\hline Tahun & Laba / Rugi Bersih & Penjualan \\
\hline 2016 & 688.400 .000 .000 & 4.935 .900 .000 .000 \\
\hline 2017 & 595.100 .000 .000 & 5.938 .600 .000 .000 \\
\hline 2018 & 688.400 .000 .000 & 7.239 .800 .000 .000 \\
\hline 2019 & 984.600 .000 .000 & 8.142 .700 .000 .000 \\
\hline
\end{tabular}

Dari tabel diatas dapat dilihat bahwa penjualan dari tahun 2016 sampai tahun 2017 mengalami peningkatan, sedangkan laba bersihnya mengalami penurunan. Laba bersih dari tahun 2017 sampai tahun
2019 mengalami peningkatanan, begitu pula dengan penjualannya juga mengalami peningkatan.

\section{Perumusan Masalah}

Berdasarkan latar belakang yang telah diuraikan sebelumnya, maka rumusan masalah sebagai berikut:

1. Bagaimana kinerja keuangan pada PT. Ace Hardware Indonesia Tbk (AHI) selama tahun 2016 - 2019 berdasarkan net profit margin?

2. Bagaimana kinerja keuangan pada PT. Ace Hardware Indonesia Tbk (AHI) selama tahun 2016 - 2019 berdasarkan return on assets?

3. Bagaimana kinerja keuangan pada PT. Ace Hardware Indonesia Tbk (AHI) selama tahun 2016 - 2019 berdasarkan return on equity?

\section{Tujuan Penelitian}

Tujuan penulis mengadakan penelitian ini, yaitu:

1. Untuk mengetahui dan menganalisis bagaimana kinerja keuangan pada PT. Ace Hardware Indonesia Tbk (AHI) selama tahun 2016-2019 berdasarkan Net Profit Margin.

2. Untuk mengetahui dan menganalisis bagaimana kinerja keuangan pada PT. Ace Hardware Indonesia Tbk (AHI) selama tahun 2016 -2019 berdasarkan Return On Assets.

3. Untuk mengetahui dan menganalisis bagaimana kinerja keuangan pada PT. Ace Hardware Indonesia Tbk (AHI) selama tahun 2016-2019 berdasarkan Return On Equity.

\section{KAJIAN TEORITIS}

\section{Manajemen Keuangan}

Menurut Sudana (2011:1), Bahwa Manajemen keuangan perusahaan adalah salah satu bidang manajemen fungsional perusahaan yang berhubungan dengan pengambilan keputusan investasi jangka panjang, dan pengelolaan modal kerja perusahaan yang meliputi investasi dan pendanaan jangka pendek. Dengan kata lain manajemen keuangan perusahaan merupakan bidang keuangan yang menerapkan prisnispprinsip keuangan dalam suatu organisasi perusahaan untuk mencapai dan mempertahankan nilai melalui pengambilan keputusan dan pengelolaan sumber daya yang tepat.

Menurut Agus Sartono (2015:6), Manajemen Keuangan dapat diartikan sebagai manajemen dana yang baik yang berkaitan dengan pengalokasian dana dalam berbagai bentuk investasi secara efektif maupun usaha pengumpulan untuk pembiayaan investasi atau pembelajaran secara efisien. 


\section{Laporan Keuangan}

Laporan keuangan pada dasarnya adalah hasil dari proses akuntansi yang dapat digunakan sebagai alat komunikasi antara data keuangan atau aktivitas suatu perusahaan dengan pihak- pihak yang berkepentingan dengan data atau aktivitas perusahaan tersebut.

Pengertian laporan keuangan adalah laporan yang menunjukkan kondisi keuangan perusahaan pada saat ini atau dalam suatu periode tertentu. Laporan keuangan merupakan suatu informasi yang menggambarkan kondisi keuangan suatu perusahaan, dan lebih jauh informasi tersebut dapat dijadikan sebagai gambaran kinerja keuangan perusahaan tersebut.

Laporan keuangan pada umumnya terdiri dari neraca dan perhitungan laba rugi serta laporan perubahan ekuitas. Neraca menunjukkan/ menggambarkan jumlah asset, kewajiban dan ekuitas dari suatu perusahaan pada tanggal tertentu. Sedangkan perhitungan (laporan) laba rugi memperlihatkan hasil- hasil yang telah dicapai oleh perusahaan serta beban yang terjadi selama periode tertentu, dan laporan perubahan ekuitas menunjukkan sember dan penggunaan atau alasan- alasan yang menyebabkan perubahan ekuitas suatu perusahaan.

\section{Analisis Laporan Keuangan}

Setelah laporan keuangan disusun berdsarkan data yang relevan, serta dilakuan dengan prosedur akuntansi dan penilaian yang benar, akan terlihat kondisi keuangan perusahaan yang sesungguhnya. Kondisi keuangan yang dimaksud adalah diketahui berapa jumlah harta (Kekayaan), kewajiban (Utang), serta modal (Ekuitas) dalam neraca yang dimiliki. Kemudian juga akan diketahui jumlah pendapatan yang akan diterima dan jumlah biaya yang dikeluarkan selama periode tertentu.

Agar laporan keuangan menjadi lebih berarti sehingga dapat dipahami dan dimengerti oleh berbagai pihak, perlu dilakukan anlisis laporan keuangan. Dengan mengetahui posisi keuangan, setelah dilakukan analisis laporan keuangan secara mendalam, akan terlihat apakah perusahaan dapat mencapai target yang telah direncanakan sebelumnya atau tidak.

\section{Analisis Rasio Keuangan}

Analisis laporan keuangan penting dilakukan untuk mengetahui kekuatan dan kelemahan suatu perusahaan. Informasi ini diperlukan untuk mengevaluasi kinerja yang dicapai manajemen perusahaan di masa yang lalu, dan juga untuk bahan pertimbangan dalam menyusun rencana perusahaan kedepan. Salah satu cara memperileh informasi yang bermanfaat dari laporan keuangan perusahaan adalah dengan melakukan analisis rasio keuangan. Rasio keuangan didesain untuk memperlihatkan hubungan antar akun pada laporan keuangan (neraca dan laporan laba rugi).

Rasio keuangan adalah angka yang diperoleh dari hasil perbandingan dari satu pos laporan keuangan dengan pos lainnya yang mempunyai hubungan yang relevan dan signifikan (berarti).

Menurut Warsono, jenis rasio keuangan dikelompokkan menjadi:

1) Rasio Likuiditas (Liquidity Ratios) Rasio likuiditas adalah suatu rasio keuangan yang menunjukkan kemampuan perusahaan dalam memenuhi kewajiban- kewajiban jangka pendeknya. Pada prinsipnya, semakin tinggi rasio likuiditas, maka semakin baik kemampuan perusahaan dalam memenuhi kewajiban jangka pendeknya.

2) Rasio Leverage (Leverage Ratios) Rasio Leverage/utang atau solvabilitas adalah rasio keuangan yang digunakan untuk mengukur kemampuan perusahaan dalam memenuhi kewajiban- kewajiban jangka panjangnya.

3) Rasio Aktivitas (Activity Ratios) Rasio aktivitas adalah rasio keuangan yang mengukur bagaimana perusahaan secara efektif mengelola aktivaaktivanya.

4) Rasio Profitabilitas (Profitability Ratios) Rasio profitabilitas memperlihatkan pengaruh kombinasi likuiditas, aktivitas, dan leverage terhadap hasil operasi. Rasio profitabilitas mengukur seberapa besar kemampuan perusahaan dalam menghasilkan keuntungan.

\section{Rasio Profitabilitas}

Rasio profitabilitas merupakan rasio untuk menilai kemampuan perusahaan dalam mencari keuntungan. Rasio ini juga memberikan ukuran tingkat efektivitas menajemen suatu perusahaan. Hal ini ditunjukkan oleh laba yang dihasilkan dari penjualan dan pendapatan investasi. Intinya dalah penggunaan rasio ini menunjukkan efesiensi perusahaan.

Dalam praktiknya, jenis- jenis rasio profitabilitas yang dapat digunakan adalah:

1) Net Profit Margin

Rasio ini digunakan untuk mengukur kemampuan perusahaan untuk menghasilkan laba bersih dari penjualan yang dilakukan perusahaan. margin laba bersih merupakan 
ukuran keuntungan dengan membandingkan antara laba setelah bunga dan pajak dengan penjualan. Rasio ini menunjukkan pendapatan bersih perusahaan atas penjualan. Semakin besar rasio ini semakin baik karena dianggap kemampuan perusahaan dalam mendapatkan laba cukup tinggi. Rumus dari net profit margin yaitu:

Net profit margin $=$ Laba bersih setelah pajak Penjualan bersih

2) Return on Assets (ROA)

ROA menunjukkan kemampuan perusahaan dengan menggunakan seluruh aktiva yang dimiliki untuk menghasilkan laba setelah pajak. Rasio ini penting bagi pihak manajemen untuk mengevaluasi efektifitas dan efisiensi manajemen perusahaan dalam mengelola seluruh aktiva perusahaan. Semakin besar ROA, maka semakin efisien penggunaan aktiva perusahaan atau dengan kata lain dengan jumlah aktiva yang sama bisa dihasilkan laba yang lebih besar, dan begitu pula sebaliknya. Rumus dari return on aseets yaitu:

Return on Assets $=\underline{\text { Laba bersih setelah pajak }}$ Total aktiva

3) Return on Equity (ROE)

ROE menunjukkan kemampuan perusahaan untuk menghasilkan laba setelah pajak dengan menggunakan modal sendiri yang dimiliki perusahaan. Rasio ini penting bagi pemegang saham untuk mengetahui efektifitas dan efisiensi pengelolaan modal sendiri yang dilakukan oleh pihak manajemen perusahaan. Semakin tinggi rasio ini berarti semakin efisien penggunaan modal sendiri yang dilakukan oleh pihak manajemen perusahaan. Rumus dari return on equity yaitu:

Return on equity $=\underline{\text { Laba bersih setelah pajak }}$ Total modal sendiri

\section{Kerangka Pemikiran}

Adapun kerangka pemikirian ini dapat digambarkan dalam skema sebagai berikut:

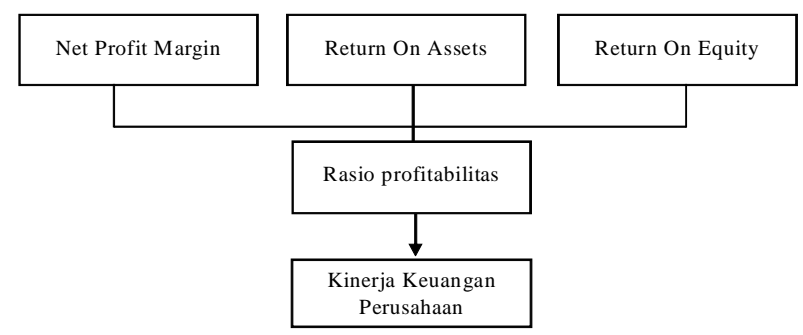

\section{Hipotesis}

Hipotesis adalah jawaban sementara terhadap rumusan masalah penelitian. Dikatakan sementara karena jawabannya baru menunggu teori. Untuk membuktikan kebenaran jawaban yang masih sementara (hipotesis) itu, maka peneliti perlu melakukan pengumpulan data pada obyek tertentu. (Ayuningtyas, 2009).

Maka peneliti mengajukan hipotesis dalam penelitian ini untuk menjawab rumusan masalah sebagai berikut: "Rasio profitabilitas dapat mengukur/ menilai kinerja keuangan di suatu perusahaan."

\section{METODOLOGI PENELITIAN \\ Populasi dan Teknik Penetapan Sampel}

1. Populasi

Populasi digunakan untuk menyebutkan seluruh elemen /anggota dari suatu wilayah yang menjadi sasaran penelitian atau merupakan keseluruhan dari objek penelitian. Populasi yang diambil dalam penelitian ini adalah laporan keuangan PT. Ace Hardware Indonesia Tbk (AHI) yaitu tahun 2016 - 2019 yang dipublikasikan di Bursa Efek Indonesia.

2. Sampel

Adapun sampel pada penelitian ini adalah laporan keuangan PT. Ace Hardware Indonesia Tbk (AHI) tahun 2016 - 2019 laporan keuangan per triwulannya dari tahun 2016 triwulan I September 2019 tahun terakhir.

\section{Pengujian Asumsi-Asumsi Model Regresi \\ 1. Uji Normalitas}

Uji normalitas pada model regresi digunakan untuk menguji apakah nilai residual yang dihasilkan dari regresi berdistribusi secara normal atau tidak. Dimana dalam penelitian ini peneliti hanya menggunakan metode grafik untuk mengetahui kenormalan suatu data, yaitu dengan melihat penyebaran data pada sumber diagonal pada grafik normal p-p plot of regression standardized residual. Sebagai dasar keputusannya, jika titik-titik menyebar sekitar garis dan mengikuti garis diagonal, maka nilai residual tersebut telah normal.

\section{Uji Multikolinearitas}

Multikolinieritas artinya antar variabel independen yang terdapat dalam model regresi memiliki linear yang sempurna atau mendekati sempurna. Untuk mendeteksi adanya multikolineritas inflation factor (VIF) pada model regresi. Apabila nilai VIF kurang dari 10 maka 
dinyatakan tidak terjadi multikolineritas, dan sebaliknya apabila VIF lebih dari 10 maka dinyatakan terjadi multikolineritas.

3. Uji Autokorelasi

Autokorelasi merupakan korelasi antara anggota observasi yang disusun menurut waktu atau tempat. Metode pengujian menggunakan uji durbin-watson (DW Test). Pengambilan keputusan pada uji durbin watson sebagai berikut:

1) $\mathrm{DU}<\mathrm{DW}<4-\mathrm{DU}$ maka Ho diterima, artinya tidak terjadi autokorelasi.

2) $\mathrm{DW}<\mathrm{DL}$ atau DW $>4-\mathrm{DL}$ maka $\mathrm{Ho}$ ditolak, artinya terjadi autokorelasi.

3) DL $<$ DW $<$ DU atau 4-DU $<$ DW $<4-$ DL, artinya tidak ada kepastian atau kesimpulan yang pasti.

4. Uji Heterokedastisitas

Heterokedastisitas adalah varian residual yang tidak sama pada semua pengamatan di dalam model regresi. Uji heterokedastisitas pada penelitian ini menggunakan metode pola grafik regresi. Apabila titik-titik tidak membentuk pola yang jelas, dan titik-titik menyebar di atas dan di bawah angka nol pada sumbu y, dapat disimpulkan bahwa tidak terjadi masalah heterokedastisitas dalam model regresi. Namun jika ada pola tertentu, seperti titik-titik yang bergelombang, melebar kemudian menyempit, maka terjadi heterokedastisitas.

\section{Metode Analisis Data}

\section{Analisis Regresi Linier Berganda}

Dalam penelitian ini terdapat tiga variabel independen yaitu ROA, ROE dan NPM yang mempengaruhi variabel dependen yaitu modal kerja. Oleh karena itu penelitian ini menggunakan analisis regresi linear berganda. Analisis regresi linear berganda menggambarkan pengaruh antara variabel bebas dan variabel terikat. Maka persamaan regresi linear mengacu pada pendapat (Algifari,2015:56) sebagai berikut :

$\mathrm{KK}=\mathrm{a}+\mathrm{b} 1 \mathrm{ROA}+\mathrm{b} 2 \mathrm{ROE}+\mathrm{b} 3 \mathrm{NPM}$

Keterangan :

$\begin{array}{ll}\text { KK } & =\text { Kinerja Keuangan } \\ \mathrm{a} & =\text { Konstanta } \\ \mathrm{b} 1, \mathrm{~b} 2, \mathrm{~b} 3 & =\text { Koefisien Regresi } \\ \mathrm{ROA} & =\text { Return on Assets } \\ \mathrm{ROE} & =\text { Return on Equity } \\ \text { NPM } & =\text { Net Profit Margin }\end{array}$

\section{Pengujian Hipotesis}

1. Uji Signifikansi Individual (Uji Statistik t) Pada penelitian ini peneliti menggunakan hipotesis asosiatif yaitu pernyataan yang menunjukkan dugaan tentang hubungan antara dua variabel atau lebih.Uji yang digunakan dengan uji dua arah. Uji dua arah dengan nilai á dibagi dua, karena á/2=0,025 diletakkan di kedua sisi. Cara pengujiannya hipotesisnya adalah : t tabel d" t hitung d" $t$ tabel maka Ho diterima dan Ha ditolak.

t tabel e" t hitung e" t tabel maka Ho ditolak dan Ha diterima.

\section{Uji Signifikansi Simultan (Uji Statistik F)}

Uji statistik F pada dasarnya menunjukkan apakah semua variable bebas yang dimasukkan dalam model mempunyai pengaruh secara bersama-sama. Koefisien regresi diuji secara serentak dengan menggunakan ANOVA, untuk mengetahui apakah mempunyai pengaruh yang signifikan terhadap model. Statistik uji yang digunakan adalah :

Jika $\mathrm{F}$ hitung < $\mathrm{F}$ tabel maka Ho diterima dan Ha ditolak.

Jika F hitung > F tabel maka Ho ditolak dan Ha diterima.

\section{Koefisien Determinasi $\left(\mathbf{R}^{2}\right)$}

Koefisien determinasi $\left(\mathrm{R}^{2}\right)$ pada intinya mengukur seberapa jauh kemampuan model dalam menerangkan variabel terikat, Semakin besar nilai $\mathrm{R}^{2}$ (mendekati 1), maka ketepatannya dikatakan semakin baik. Koefisien determinasi $\left(\mathrm{r}^{2}\right)$ untuk mengukur tepat/ cocoknya persamaan regresi untuk meramalkan. Makin besar $\mathrm{r}^{2}$, makin tepat garis untuk meramalkan $\mathrm{Y}$, sebab makin persentase sumbangan $\mathrm{X}$ terhadap variasi (naik turunnya) $\mathrm{Y}$ digunakan standard error regresi atau standard error kesalahan pengganggu.

\section{ANALISIS DAN PEMBAHASAN PENELITIAN \\ Deskripsi Objek Penelitian}

PT. Ace Hardware Indoneisa Tbk (AHI) berdiri pada tahun 1995. Gerai pertama dibuka pada tahun 1996 di Karawaci, Tangerang, Jawa Barat. Perusahaan ini terus berkembang sebagai perusahaan ritel dan kini telah menjadi perusahaan terkemuka di sektor ritel perlengkapan rumah tangga dan gaya hidup di Indonesia. Untuk menawarkan produk terbaik dan berkualitas kepada konsumen di seluruh Indonesia, PT. Ace Hardware Indonesia Tbk (AHI) terus menambah jumlah gerai baru. Sampai dengan 
tahun 2019, perusahaan ini telah memiliki 197 gerai dengan luas total mencapai $474.380 \mathrm{~m}^{2}$ dan tersebar di 45 kota dan 26 provinsi di Indonesia, termasuk pembukaan Ace Xpress di tahun 2018 yang berupa gerai dengan luas kurang dari $1000 \mathrm{~m}^{2}$. Tak berhenti sampai disitu, perusahaan ini terus menambah gerai hingga sampai dengan Juli 2020, tercatat bahwa sebanyak 205 gerai telah dibuka di seluruh Indonesia.

Bersama dengan Group, PT. Ace Hardware Indonesia Tbk (AHI) meluncurkan sebuah situs belanja online dengan nama "Ruparupa" (www.ruparupa.com) pada 25 April 2016. Hal ini didasari oleh perkembangan teknologi yang pesat dan akses informasi yang semakin mudah, perusahaan ini ingin memberikan kenyamanan dan kemudahan bagi konsumennya yaitu berupa situs web online shopping. Sampai dengan 2019, lebih dari 60.000 produk tersedia dalam 10 kategori, seperti rumah tangga, dapur minimalis, bed and bath, mebel, otomotif, hobi dan gaya hidup, kesehatan dan olahraga, elektronik dan gadget, mainan dan bayi, serta kategori best deals.

Kemudahan lainnya dalam Ruparupa.com ialah tersedianya fitur express delivery yang merupakan kerja sama dengan Gojek (GoSend). Fitur ini memudahkan konsumen dalam mendapatkan produk dengan lebih cepat (Instant Delivery atau Same-day Service). Sedangkan dalam proses pembayaran, konsumen dapat membayar secara online melalui Gopay dan OVO.

\section{A. Net Profit Margin (NPM)}

Net profit margin atau margin laba bersih adalah rasio profitabilitas yang menyatakan keuntungan dari operasi bisnis sebagai persentase dari pendapatan atau penjualan bersih.

$$
\begin{aligned}
& \text { Net Profit Margin }=\frac{\text { Laba Bersih Setelah Pajak }}{\text { Penjualan Bersih }} \\
& \mathrm{NPM}_{2016}=\frac{688.400 .000 .000}{4.935 .900 .000 .000} \times 100 \%=14 \% \\
& \mathrm{NPM}_{2017}=\frac{595.100 .000 .000}{5.938 .600 .000 .000} \times 100 \%=10 \% \\
& \mathrm{NPM}_{2018}=\frac{688.400 .000 .000}{7.239 .800 .000 .000} \times 100 \%=10 \% \\
& \mathrm{NPM}_{2019}=\frac{984.600 .000 .000}{8.142 .700 .000 .000} \times 100 \%=12 \%
\end{aligned}
$$

B. Return On Assets (ROA)

Return on Assets merupakan rasio yang menunjukkan hasil dari jumlah aset yang digunakan dalam perusahaan atau suatu ukuran tentang efisiensi manajemen.
Return On Assets $=\frac{\text { Laba Bersih Setelah Pajak }}{\text { Total Aktiva }}$

$$
\begin{array}{ll}
\mathrm{ROA}_{2016} & =\frac{688.400 .000 .000}{3.731 .100 .000 .000} \times 100 \%=18 \% \\
\mathrm{ROA}_{2017} & =\frac{595.100 .000 .000}{4.428 .800 .000 .000} \times 100 \%=13 \% \\
\mathrm{ROA}_{2018} & =\frac{688.400 .000 .000}{5.320 .900 .000 .000} \times 100 \%=13 \% \\
\mathrm{ROA}_{2019} & =\frac{984.600 .000 .000}{5.920 .200 .000 .000} \times 100 \%=16 \%
\end{array}
$$

C. Return On Equity

Return On Equity merupakan rasio profitabilitas untuk mengukur kemampuan suatu perusahaan dalam menghasilkan laba dari investasi yang dilakukan pemegang saham pada perusahaan tersebut.

$$
\text { Return On Equity }=\frac{\text { Laba Bersih Setelah Pajak }}{\text { Total Modal Sendiri }}
$$

$$
\begin{array}{ll}
\mathrm{ROE}_{2016} & =\frac{688.400 .000 .000}{1.510 .700 .000 .000} \times 100 \%=45 \% \\
\mathrm{ROE}_{2017} & =\frac{595.100 .000 .000}{1.770 .300 .000 .000} \times 100 \%=35 \% \\
\mathrm{ROE}_{2018} & =\frac{688.400 .000 .000}{2.358 .800 .000 .000} \times 100 \%=29 \% \\
\mathrm{ROE}_{2019} & =\frac{984.600 .000 .000}{2.564 .300 .000 .000} \times 100 \%=38 \%
\end{array}
$$

D. (Economic Value Added)

Eva adalah suatu ukuran kinerja keuangan yang didasarkan suatu nilai (value-based) yang dinyatakan dalam satuan mata uang (misalnya Rupiah). Oleh karena nilai EVAtidak dinyatakan dalam angka relative, maka tidak ada batasan nilai EVA yang ideal yang menyatakan seberapa baik atau seberapa buruknya kinerja keuangan suatu perusahaan.

$$
\begin{array}{ll}
\mathrm{EVA}=\text { Net Operating After Tax (NOPAT) }- \text { Capital Charges } \\
\mathrm{EVA}_{2016} & =718.841 .787 .126-648.435 .047 .800 \\
& =70.406 .739 .326 \\
\mathrm{EVA}_{2017} & =785.494 .939 .535-695.311 .232 .000 \\
& =90.183 .707 .535 \\
\mathrm{EVA}_{2018} & =990.665 .066 .440-877.053 .449 .800 \\
& =113.611 .616 .640 \\
\mathrm{EVA}_{2019} & =1.057 .536 .700 .000-952.754 .131 .400 \\
& =104.782 .568 .600
\end{array}
$$


Tabel 4.1 Standar Rasio Industri Profitabilitas

\begin{tabular}{|c|r|}
\hline Jenis Rasio & Standar Ind \\
\hline Net Profit Margin & $>20 \%$ \\
\hline Return On Assets & $>30 \%$ \\
\hline Return On Equity & $>40 \%$ \\
\hline \multicolumn{2}{|c|}{ Sumber : Kasmir (2008:208) }
\end{tabular}

Tabel 4.2 Hasil Perhitungan Rasio Keı

PT. Ace Hardware Indonesia Tbk ( (Hasil disajikan dalam \%)

\begin{tabular}{|c|c|c|c|c|c|c|c|}
\hline \multirow[t]{2}{*}{ Keterangan } & \multicolumn{4}{|c|}{ Tahun } & \multirow{2}{*}{$\begin{array}{l}\text { Rata- } \\
\text { Rata }\end{array}$} & \multirow[t]{2}{*}{$\overline{\text { Sta }}$} & \\
\hline & 2016 & 2017 & 2018 & 2019 & & & \\
\hline \multicolumn{8}{|l|}{ Profitabilitas } \\
\hline NPM & $14 \%$ & $10 \%$ & $10 \%$ & $12 \%$ & $11.5 \%$ & $>2$ & \\
\hline ROA & $18 \%$ & $13 \%$ & $13 \%$ & $16 \%$ & $15 \%$ & $>3 \mathrm{v} \%$ & $\begin{array}{c}\text { nurauly } \\
\text { Baik }\end{array}$ \\
\hline ROE & $45 \%$ & $35 \%$ & $29 \%$ & $38 \%$ & $37 \%$ & $>40 \%$ & Baik \\
\hline
\end{tabular}

Sumber: data diolah

\section{Uji Asumsi Klasik}

\section{Uji Normalitas}

Uji normalitas adalah untuk menguji apakah data observasi berdistribusi normal sehingga dapat dilakukan pengujian terhadap data. Pengujian normalitas data bertujuan untuk menguji apakah dalam sebuah model regresi linier berdistribusi normal. Untuk menguji normalitas data menggunakan Kolmogorov-Smirnov. Jika nilai signifikasi penelitian lebih dari 0,05 maka data diasumsikan berdistribusi normal.

Nilai uji Kolmogorov-Smirnov yang dilah bersama-sama dapat dilihat pada tabel dibawah:

\section{Tabel 4.3}

Tests of Normality

\begin{tabular}{|l|r|r|r|r|r|r|}
\hline & \multicolumn{3}{|c|}{ Kolmogorov-Smirnov $^{\text {a }}$} & \multicolumn{3}{|c|}{ Shapiro-Wilk } \\
\cline { 2 - 7 } & Statistic & df & Sig. & Statistic & df & Sig. \\
\hline Unstandardized Residual & .185 & 4 & & .993 & 4 & .971 \\
\hline
\end{tabular}

a. Lilliefors Significance Correction

a. Test distribution is Normal

b. Calculated from data.

Sumber : SPSS version 25

Pada penelitian ini dari seluruh variabel yang mempunyai nilai signifikan lebih dari 0,05 dan sama dengan 0,05 adalah variabel NPM, ROA dan ROE sehingga dapat diasumsikan bahwa data yang diolah mempunyai distribusi normal.

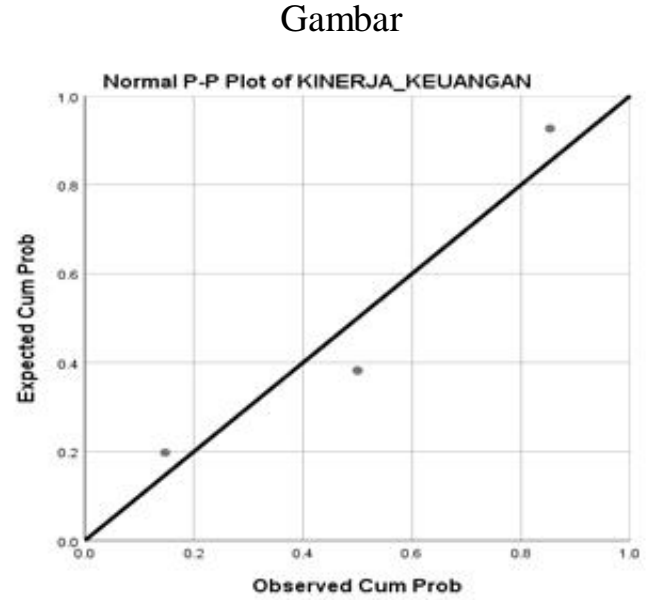

Sumber : SPSS version 25

Berdasarkan Gambar 4.1 dapat diketahui penyebaran data (titik) disekitar sumbu diagonal dan mengikuti arah garis diagonal, maka menunjukkan model regresi yang memenuhi asumsi normalitas. Hal ini dapat diartikan bahwa data dalam penelitian ini telah berdistribusi normal.

\section{Uji Multikolinearitas}

Tabel 4.4 Uji Multikolinearitas

\begin{tabular}{|l|l|c|l|}
\hline \multicolumn{4}{|c|}{ Coefficients } \\
\hline Model & Coliniearity Statistics & & \\
\hline & Tolerance & VIF & Keterangan \\
\hline Constant & & & \\
\hline ROA & 0,160 & 6,242 & Bebas Multikolinearitas \\
\hline ROE & 0,118 & 8,510 & Bebas Multikolinearitas \\
\hline NPM & 0,247 & 4,045 & Bebas Multikolinearitas \\
\hline $\begin{array}{l}\text { a. Dependent Variable: } \\
\text { KINERJA KEUANGAN }\end{array}$ & & \\
\hline
\end{tabular}

Sumber : SPSS version 25

Berdasarkan Tabel 4.4 menunjukkan hasil uji multikolinearitas dengan Tolerance dan Variance Inflation Factor (VIF). Diketahui bahwa tidak terdapat variabel independen yang memiliki nilai Tolerance kurang dari 0,10 . Sedangkan, hasil perhitungan Variance Inflation Factor (VIF) juga tidak terdapat variabel independen yang memiliki nilai VIF lebih dari 10. Maka dapat disimpulkan bahwa tidak mengandung multikolinear antar variable independen dalam perhitungan model regresi. 


\section{Uji Autokorelasi}

Tabel 4.5 Uji Autokorelasi

\begin{tabular}{|l|c|r|r|r|r|}
\hline Model & $\mathrm{R}$ & $\mathrm{R}$ Rquare & $\begin{array}{c}\text { Adjusted } \\
\text { R Square }\end{array}$ & $\begin{array}{c}\text { Std. Error of } \\
\text { the Estimate }\end{array}$ & $\begin{array}{c}\text { Durbin- } \\
\text { Watson }\end{array}$ \\
\hline 1 & $1.000^{\mathrm{a}}$ & 1.000 &. & & 3.134 \\
\hline a. Predictors: (Constant), ROE, NPM, ROA \\
b. Dependent Variable: KINERJA KEUANGAN
\end{tabular}

Sumber : SPSS Versi 25

Berdasarkan Tabel 4.5 perhitungan uji autokorelasi di peroleh nilai Durbin Watson sebesar 3,134. Di mana terletak diantara -4 sampai +4 maka dapat disimpulkan bahwa model regresi yang akan digunakan tidak terdapat masalah autokorelasi

\section{Uji Heterokedasitas}

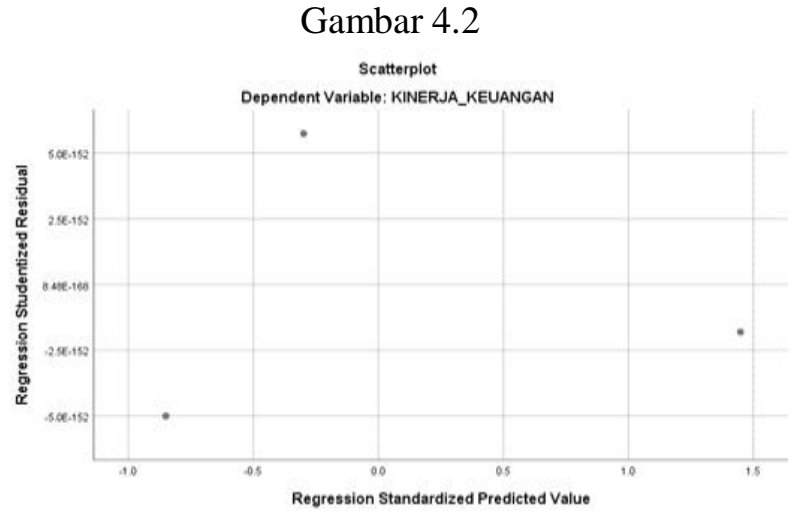

Berdasarkan Gambar 4.2 grafik scatterplots terlihat bahwa titik-titik menyebar secara acak tersebar baik diatas maupun dibawah angka 0 pada sumbu Y. Maka dapat disimpulkan bahwa model pada penelitian ini telah memenuhi syarat untuk dapat dijadikan sebagai bahan penelitian yang baik karena model regresi terjadi kesamaan varian residual dari satu pengamatan ke pengamatan lainnya disebut dengan homoskedastisitas. Sehingga, model regresi dapat layak untuk digunakan memprediksi kinerja keuangan melalui variabel independen yaitu ROA, ROE, dan NPM.

\section{Analisis Data}

Analisis Regresi Linier Berganda

Tabel 4.6 Analisis Regresi Linier Berganda

\begin{tabular}{|l|c|c|c|c|c|}
\hline Model & \multicolumn{2}{|l|}{ Unstandardized Coefficients } & $\begin{array}{c}\text { Standarized } \\
\text { Coefficients }\end{array}$ & T & Sig. \\
\hline & B & Std. Error & Beta & & \\
\hline (Constant) & 0,918 & 0,592 & & 1,552 & 0,128 \\
\hline ROA & 0.564 & 0,108 & 0,563 & 5,228 & 0,000 \\
\hline ROE & 0,350 & 0,138 & 0,318 & 2,533 & 0,015 \\
\hline NPM & 0,122 & 0,093 & 0,113 & 1,309 & 0,198 \\
\hline
\end{tabular}

Sumber : SPSS version 25

Berdasarkan Tabel 4.6 persamaan regresi linier berganda dalam penelitian ini menggunakan beta koefisien tidak standart (Unstandardized Coefficient) disebabkan karena masing-masing variabel mempunyai satuan fungsi yang berbeda-beda dengan menjelaskan besarnya koefisien regresi masingmasing variabel bebas terhadap variabel terikatnya, maka dapat dijelaskan dengan rumus:

$\mathrm{KK}=0,918+0,564 \mathrm{ROA}+0,350 \mathrm{ROE}+0,122 \mathrm{NPM}$

Persamaan regresi diatas dapat dijelaskan sebagai berikut:

1) Persamaan regresi diatas menjelaskan bahwa nilai konstanta sebesar 0,918. Artinya, jika variabel ROA, ROE dan NPM adalah sama dengan nol $(=0)$ maka kinerja keuangan sebesar 0,918.

2) Koefisien regresi ROA memiliki nilai sebesar 0,564 . Hasil tersebut dapat menjelaskan bahwa variabel ROA memiliki hubungan yang positif dan dapat berbanding lurus atau searah antara ROA dengan kinerja keuangan. Artinya, semakin tinggi ROA maka semakin baik kinerja perusahaan dalam mengelola kinerja keuangan akan meningkat sebesar 0,564 dan dapat diasumsikan bahwa variabel lainnya adalah konstan.

3) Koefisien regresi ROE memiliki nilai sebesar 0,350. Hasil tersebut dapat menjelaskan bahwa variabel ROE memiliki hubungan yang positif dan dapat berbanding lurus atau searah antara ROE dengan kinerja keuangan. Artinya, semakin tinggi ROE maka semakin baik perusahaan dalam mengelola kinerja keuangan akan meningkat sebesar 0,350 dan dapat diasumsikan bahwa variabel lainnya adalah konstan.

4) Koefisien regresi NPM memiliki nilai sebesar 0,122 . Hasil tersebut menjelaskan bahwa variabel NPM memiliki hubungan yang positif dan dapat berbanding lurus atau searah antara NPM dengan kinerja keuangan. Artinya, semakin tinggi NPM maka semakin efisien operasional perusahaan dalam mengelola kinerja keuangan sebesar 0,122 dan dapat diasumsikan bahwa variabel lainnya adalah konstan.

Pengujian Hipotesis

Uji Statistik t

Tabel 4.7Uji Hipotesis (Uji t)

\begin{tabular}{|c|c|c|c|c|c|}
\hline Model & Unstar & oefficients & Standarized & $\begin{array}{ll}T \\
\end{array}$ & Sig. \\
\hline & B & Std. Error & Beta & & \\
\hline (Constant) & 0,918 & 0,592 & & 1,552 & 0,128 \\
\hline ROA & 0.564 & 0,108 & 0,563 & 5,228 & 0,000 \\
\hline $\mathrm{ROE}$ & 0,350 & 0,138 & 0,318 & 2,533 & 0,015 \\
\hline NPM & 0,122 & 0,093 & 0,113 & 1,309 & 0,198 \\
\hline
\end{tabular}


Berdasarkan Tabel 4.7 hasil perhitungan nilai t di peroleh sebagai berikut:

1) Pengaruh ROA terhadap Kinerja Keuangan. Variabel ROA dengan nilai t sebesar 5,228 dan hasil signifikansi sebesar 0,000 berarti á $<0,05$. Maka $\mathrm{H}_{\mathrm{a}}$ diterima, dapat disimpulkan bahwa variabel ROA berpengaruh signifikan terhadap kinerja keuangan pada perusahaan PT. Ace Hardware Indonesia Tbk (AHI).

2) Pengaruh ROE terhadap Kinerja Keuangan. Variabel ROE dengan nilai t 2,533 dan hasil signifikansi sebesar 0,015 berarti á $<0,05$. Maka $\mathrm{H}_{\mathrm{a}}$ diterima, dapat disimpulkan bahwa variabel ROE berpengaruh signifikan terhadap kinerja keuangan pada perusahaan PT. Ace Hardware Indonesia Tbk (AHI).

3) Pengaruh NPM terhadap Kinerja KeuanganVariabel NPM dengan nilai t sebesar 1,309 dan hasil signifikansi sebesar 0,198 berarti á > 0,05. Maka $\mathrm{H}_{a}$ ditolak, dapat disimpulkan bahwa variabel NPM berpengaruh tidak signifikan terhadap kinerja keuangan pada perusahaan PT. Ace Hardware Indonesia Tbk (AHI).

\section{Uji Statistik f}

Tabel 4.8 Uji Hipotesis (Uji f)

\begin{tabular}{|l|c|c|c|c|c|}
\hline \multicolumn{7}{|c|}{ ANOVA $^{\text {a }}$} \\
\hline \multicolumn{1}{|c|}{ Model } & Sum of Squares & Df & Mean Square & F & Sig. \\
\hline $\mathbf{1}$ Regression & 135,626 & 3 & 45,209 & 166,120 & $0,000^{\mathrm{b}}$ \\
\hline \multicolumn{1}{|c|}{ Residual } & 10,886 & 40 & 0,272 & & \\
\hline \multicolumn{1}{|c|}{ Total } & 146,512 & 43 & & & \\
\hline $\begin{array}{l}\text { a. Dependent Variable: } \\
\text { KINERJA KEUANGAN }\end{array}$ & & & & \\
\hline $\begin{array}{l}\text { b. Predictor: (Constant), ROA, ROE, } \\
\text { NPM }\end{array}$ & & & & \\
\hline
\end{tabular}

Sumber : SPSS version 25

Berdasarkan Tabel 4.8 dapat diketahui bahwa pvalue (pada kolom Sig.) < level of significant $(0,05)$ atau $0,000<0,05$. Maka data tersebut dapat dikatakan layak untuk dijadikan penelitian.

\section{Uji Koefisien Determinasi $\left(\mathbf{R}^{\mathbf{2}}\right)$}

Tabel 4.9 Uji Koefisien Determinasi $\left(\mathrm{R}^{2}\right)$

Model Summary ${ }^{\text {b }}$

\begin{tabular}{|c|c|c|c|c|}
\hline Model & R & R Square & $\begin{array}{c}\text { Adjusted R } \\
\text { Square }\end{array}$ & $\begin{array}{c}\text { Std. Error of the } \\
\text { Estimate }\end{array}$ \\
\hline 1 & $0,962^{\mathrm{a}}$ & 0,926 & 0,920 & 0,52168 \\
\hline
\end{tabular}

a. Predictors: (Constant), ROA, ROE, NPM

b. Dependent Variabel: KINERJA_KEUANGAN

Sumber : SPSS version 25

Berdasarkan Tabel 4.9 diperoleh $\mathrm{R}$ Square sebesar 0,926 menunjukkan variasi dari kinerja keuangan menjelaskan bahwa variabel ROA, ROE, dan NPM sebesar 92,6\% terhadap kinerja keuangan. Sedangkan, sisanya sebesar 0,074 atau $7,04 \%$ dijelaskan oleh variabel lain yang bukan termasuk dalam model penelitian. Nilai $R^{2}=0,926$ berada pada $0<0,926<1$ maka pendekatan model ini layak digunakan dalam penelitian.

\section{Pembahasan Hasil Penelitian}

Setelah melakukan pembahasan di atas, maka di dapat hasil penelitian berdasarkan teknik analisis yang digunakan pada perusahaan PT. Ace Hardware Indonesia Tbk (AHI). Di antaranya adalah :

1. Hubungan Return On Assets terhadap Kinerja Keuangan

Berdasarkan hasil koefisien linear berganda Return on Assets memiliki koefisien positif terhadap kinerja keuangan. Hal ini berarti bahwa jika Return on Assets mengalami kenaikan maka akan diikuti oleh kondisi kinerja keuangan yang membaik.

Berdasarkan hasil uji statistic t variabel ROA berpengaruh signifikan terhadap kinerja keuangan pada perusahaan PT. Ace Hardware Indonesia Tbk (AHI).

2. Hubungan Return On Equity terhadap Kinerja Keuangan

Berdasarkan hasil koefisien linear berganda Return on Equity memiliki koefisien positif terhadap kinerja keuangan. Hal ini berarti bahwa jika Return on Equity mengalami kenaikan maka akan diikuti oleh kondisi kinerja keuangan yang membaik.

Berdasarkan hasil uji statistic t variabel ROE berpengaruh signifikan terhadap kinerja keuangan pada perusahaan PT. Ace Hardware Indonesia Tbk (AHI).

3. Hubungan Net Profit Margin terhadap Kinerja Keuangan

Berdasarkan hasil koefisien linear berganda Net Profit Margin memiliki koefisien positif terhadap kinerja keuangan. Hal ini berarti bahwa jika Net Profit Margin mengalami kenaikan maka akan diikuti oleh kondisi kinerja keuangan yang membaik.

Berdasarkan hasil uji statistic t variabel NPM berpengaruh tidak signifikan terhadap kinerja keuangan pada perusahaan PT. Ace Hardware Indonesia Tbk (AHI). 


\section{KESIMPULAN, KERETBATASAN DAN REKOMENDASI \\ Kesimpulan}

Berdasarkan hasil penelitian yang dilakukan oleh peneliti pada PT. Ace Hardware Indonesia Tbk (AHI) tahun 2016-2019 maka dapat disimpulkan hasilnya sebagai berikut :

1. Return on Assets berpengaruh signifikan terhadap kinerja keuangan. Berdasarkan hasil penelitian uji hipotesis dapat disimpulkan bahwa hipotesis pertama menyatakan Return on Assets berpengaruh signifikan terhadap kinerja keuangan perusahaan diterima. Jika dilihat dari hasil koefisien linear berganda Return on Assets memiliki koefisien positif terhadap kinerja keuangan. Hal ini berarti bahwa jika Return on Assets mengalami kenaikan maka akan diikuti oleh kondisi kinerja keuangan yang membaik, begitu pula sebaliknya.

2. Return on Equity berpengaruh signifikan terhadap kinerja keuangan. Berdasarkan hasil penelitian uji hipotesis dapat disimpulkan bahwa hipotesis kedua menyatakan Return on Equity berpengaruh signifikan terhadap modal kerja perusahaan diterima. Jika dilihat dari hasil koefisien linear berganda Return on Equity memiliki koefisien positif terhadap kinerja keuangan. Hal ini berarti bahwa jika Return on Equity mengalami kenaikan maka akan diikuti oleh kondisi kinerja keuangan yang membaik, begitu pula sebaliknya.

3. Net Profit Margin berpengaruh tidak signifikan terhadap kinerja keuangan. Berdasarkan hasil penelitian uji hipotesis dapat disimpulkan bahwa hipotesis ketiga menyatakan Net Profit Margin berpengaruh tidak signifikan terhadap kinerja keuangan perusahaan ditolak. Jika dilihat dari hasil koefisien linear berganda Net Profit Margin memiliki koefisien positif terhadap kinerja keuangan. Hal ini berarti bahwa jika Net Profit Margin mengalami kenaikan maka akan diikuti oleh kondisi kinerja keuangan yang membaik, begitu pula sebaliknya.

\section{Keterbatasan}

Penelitian ini telah berusaha mengembangkan penelitian terdahulu. Namun demikian, masih terdapat beberapa keterbatasan pada penelitian ini, yaitu:

1. Keterbatasan dalam jumlah sampel yang digunakan dalam penelitian ini.

2. Penelitian ini hanya berfokus pada variabel Return On Asset, Return On Equity, dan Net
Profit Margin sedangkan masih banyak variabelvariabel lainnya yang bisa diteliti dalam mempengaruhi kinerja keuangan pada suatu perusahaan.

3. Sampel yang digunakan dalam penelitian ini hanya satu industry yaitu retail, sehingga tidak dapat dijadikan generalisasi seluruh perusahaan.

\section{Rekomendasi}

1. Penelitian lebih lanjut dapat menambah objek penelitian.

2. Penelitian lebih lanjut dapat menambah variabel lain yang belum digunakan seperti rasio likuiditas dan rasio aktivitas.

3. Penelitian selanjutnya diharapkan dapat mengembangkan variabel yaitu variabel yang memungkinkan mempengaruhi kinerja keuangan.

\section{DAFTAR PUSTAKA}

Eviana, "Analisis Rasio Profitabilitas dan Rasio Aktivitas Sebagai dasar Penilaian Kinerja Keuangan pada PT Skyline Jaya", Skripsi, Fakultas Ekonomi Universitas Wijaya Putra Surabaya, 2012.

Husnan, S. 2009. Dasar-Dasar Manajemen Keuangan. Edisi Kedua. Cetakan Pertama. UPP AMP YKPN. Yogyakarta.

Kasmir, Analisis Laporan Keuangan, Jakarta: PT. Rajagrafindo Persada, 2012.

Mardahleni,. (2017), Analisis Rasio Profitabilitas Dalam Menilai Kinerja Keuangan PT Hanjaya Manadala Sampoerna Tbk, e-jurnal Apresiasi Ekonomi, 5 (2), 65-72

Prastowo, D. dan R. Julianti. 2005. Analisis Laporan Keuangan. Edisi Kedua. UPP AMP YKPN. Yogyakarta.

PT. Ace Hardware Indonesia, "Sejarah dan Profil singkat Ace Hardware Indonesia Tbk," Britama.com.html/profil Ace Hardware Indonesia Tbk, diakses 7 July 2021 pukul 10.00 wib.

PT. Ace Hardware Indonesia Tbk, "Laba bersih Ace Hardware Indonesia Tbk" Bitama.com.html/ profil Ace Hardware Indonesia Tbk, diakses 10 July 2021 pukul 20.00 wib.

Sudana, I Made, Manajemen Keuangan Perusahaan Teori dan Praktik, Jakarta: Erlangga, 2011

Sugiono, Statistika Untuk Penelitian, Bandung: AlFabeta,2009.

Www.idx.co.id 